\title{
Dung decomposition and associated beetles in a fragmented temperate forest
}

\author{
Descomposición de heces y sus coleópteros asociados en un bosque templado fragmentado \\ MARCELA A. BUSTAMANTE-SÁNCHEZ1, AUDREY A. GREZ ${ }^{2}$ \\ $\&$ JAVIER A. SIMONETTI ${ }^{1}$ \\ ${ }^{1}$ Departamento de Ciencias Ecológicas, Facultad de Ciencias, Universidad de Chile, Casilla 653, \\ Santiago, Chile; e-mail: marbusan@yahoo.com \\ ${ }^{2}$ Facultad de Ciencias Veterinarias y Pecuarias, Universidad de Chile, Casilla 2, Correo 15, \\ La Granja, Santiago, Chile
}

\begin{abstract}
Habitat fragmentation may result in changes in species number and population abundance among habitats that differ in area, structure, or edge characteristics. These changes, in turn, may result in alterations in ecosystem process such as decomposition of organic matter. Through an experimental approach, we compared the beetles assemblages associated with dung and decomposition of cow feces in a continuous portion of Maulino forest, forest fragments and in pine plantations that surround this forest and forest remnants. Abundance and richness of dung-associated beetles were lower in forest fragments compared to the continuous forest and pine plantations. However, dung decomposition was similar in these three habitats. Beetle abundance, species richness and decomposition did not vary along edges of forest fragments and pine plantations, but beetle abundance and decomposition rate varied on the border compared to the interior of the continuous forest. Thus, although beetle assemblage changes across the fragmented landscape, these variations in species richness and abundance did not translate into alterations of an ecosystem process such as dung-decomposition, as occurs in tropical forests. The beetle assemblage at pine plantations comprises only native species and dung decomposition was similar in both fragments and continuous forest. Therefore, pine plantations maintain at least partially the structural and functional biodiversity of the native fauna, connecting the native remnants throughout the landscape, a crucial factor in biodiversity conservation.
\end{abstract}

Key words: temperate forest, fragmentation, insects, decomposition.

\section{RESUMEN}

La fragmentación del hábitat puede cambiar el número de especies y la abundancia poblacional entre hábitats que difieren en área, estructura o en las características del borde. Estos cambios, a su vez, pueden alterar procesos ecosistémicos como la descomposición de la materia orgánica. A través de una aproximación experimental, comparamos un ensamble de coleópteros asociados a heces y la descomposición de estas en una porción continua de bosque Maulino, fragmentos de bosque y en la matriz de plantaciones de pino que rodean estos remanentes de bosque. La abundancia y riqueza de coleópteros asociados a las heces fueron más bajas en los fragmentos de bosque que en el bosque continuo y en las plantaciones de pino. Sin embargo, la descomposición de las heces fue similar entre los tres hábitats. La abundancia de coleópteros, riqueza de especies y descomposición no variaron en los bordes de los fragmentos ni en los bordes de las plantaciones de pino, sin embargo, la abundancia y descomposición variaron en el borde en comparación al centro del bosque continuo. Así, aunque el ensamble de coleópteros cambia a través de este paisaje fragmentado, estos cambios no se tradujeron en alteraciones en procesos ecosistémicos como la descomposición de heces, como ocurre en bosques tropicales. El ensamble de coleópteros en las plantaciones de pino solo tuvo especies nativas y la descomposición de heces fue similar a la de los fragmentos y a la del bosque continuo. Por lo tanto, estas plantaciones de pino mantienen por lo menos parcialmente la biodiversidad estructural y funcional de la fauna nativa, conectando remanentes de bosque nativo a través del paisaje, un factor crucial en la conservación de la biodiversidad.

Palabras clave: bosque templado, fragmentación, insectos, descomposición. 


\section{INTRODUCTION}

Land use changes are a major threat to biodiversity, particularly in temperate forests. In fact, deforestation and forest fragmentation have increased worldwide, and are a significant menace to the compositional, structural and functional biodiversity (Chapin et al. 2000, Sala et al. 2000). Coupled to a reduction and isolation of the remnant forest area, fragmentation also increases the proportion of edge habitat with decreasing fragment area, modifying the microclimatic conditions in the borders and the dispersal of organisms between neighboring fragments and among isolated fragments. These changes might modify the distribution, abundance, and species richness of several groups of insects at both within each fragment and the landscape level (Didham et al. 1998, Golden \& Crist 2000). In turn, these compositional and structural biodiversity changes might translate into altered ecological processes such as reduced rates of organic matter decomposition (Didham et al. 1996).

Decomposition of dead organic matter, such as carcasses, leaf litter or dung, is a dynamic process that involves a complex array of physical, chemical and biological interactions that complete the biogeochemical nutrient cycles. This process is largely performed by microbes, but soil fauna have an important stimulatory role. Insects participate in the decomposition processes, breaking apart or consuming organic matter, or through the consumption of other organisms associated with such organic matter. Animal consumption enhances decomposition rates (Peterson \& Luxton 1982, Packham et al. 1992, Robertson \& Paul 2000). In tropical forests, species richness and abundance of beetles associated with dung decomposition are generally depressed in small forest fragments (Klein 1989, Estrada 2002, Andresen 2003). Such a decrease translates into reduced decomposition rates (Klein 1989, Andresen 2003). However, despite the paramount significance of dung decomposition to nutrient cycling and associated biogeochemical processes, few studies have addressed the effect of habitat fragmentation on this process and none of them have been carried out in temperate forests.

Like tropical ones, temperate forests in southern Chile have been extensively fragmented (San Martín \& Donoso 1997). The Maulino forest, a unique temperate ecosystem harboring several distinctive and endangered species, is currently reduced to a mosaic of isolated fragments surrounded by Monterrey pine plantations (Pinus radiata D. Don) (Bustamante \& Castor 1998, Grez et al. 1998). In this forest, ground-dwelling beetles are more diverse and abundant in small than in large forest fragments, sharply contrasting with the effects of fragmentation in tropical forests (Grez in press). Some of these beetles might be associated with the decomposition of dead organic matter. Therefore, dung decomposition could be higher in forest fragments, similar to an increased granivory and nest predation rate due to a more abundant consumer assemblages thriving in these forest remnants (Donoso et al. 2003, Vergara \& Simonetti 2003). Here, we used an experimental approach to analyze changes in ecological processes in the Maulino forest brought about by forest fragmentation, focusing on dung decomposition. Regarding beetles associated with dung and the decomposition process, we addressed the four following questions: (1) How does species composition of these beetles change with forest fragmentation? (2) Do the species richness and abundance of these beetles and dung decomposition increase in forest fragments? (3) Is there an edge effect on the beetles associated with dung and on dung decomposition? (4) Are the changes in the beetles community structure associated with changes in dung decomposition? Furthermore, in order to analyze changes in a broader perspective, we determine if the responses of the beetles and dung decomposition are similar in tropical and temperate fragmented forest.

\section{MATERIAL AND METHODS}

\section{Study area}

The study was carried out in the Maulino forest, which harbors a suite of endemic tree species, including Gomortega keule (Mol.) Baillon, the single representative of the primitive family Gomortegaceae. The dominant species is Nothofagus glauca (Phil.) Krasser (Fagaceae), which coexists with many endangered endemic species such as Nothofagus alessandrii Esp. (Fagaceae), Pitavia punctata (R. et P.) Mol. (Rutaceae) and G. keule. This forest has been intensively deforested and fragmented, initially due to increased fuel wood production and land clearing for cultivation, and more recently, due to its replacement by plantations of commercial $P$. radiata, associated to the expansion of timber production and exports (Lara et al. 1996).

The study was conducted in a continuous forest located in the coast of central Chile, in three adjacent forest fragments and in three 
pine plantations that surround the native forest. The continuous forest includes the Reserva Nacional Los Queules (3559'19', S, $\left.72^{\circ} 41^{\prime} 15^{\prime \prime} \mathrm{W}\right)$, one of the few areas allocated to preserve the Maulino forest in Chile. This reserve covers 145 ha but is embedded in 600 ha of continuous forest. Forest fragments are remnants of native forest of $3.4,3.0$ and 2.3 ha. Both continuous forest and forest fragments have a similar vegetation dominated by $N$. glauca, N. obliqua (Mirb.) Oerst, Cryptocarya alba (Mol.) Looser, Gevuina avellana Mol. (San Martín \& Donoso 1997). Pine plantations are 20 years old, with an abundant understory of native trees dominated by $N$. glauca and Aristotelia chilensis (Mol.) Stuntz and exotic shrubs as Teline monspessulana (L.) K. Koch and Rosa moschata Hermm.

\section{Experimental design}

Fieldwork was carried out during the summer from 14 November 2001 to 11 January 2002. Species richness and abundance of grounddwelling beetles are higher in summer (December-March) than in spring (SeptemberDecember, Grez et al. 2003).

We placed fresh dung piles in six different locations: the border and interior of continuous forest, forest fragments and pine plantations. The dung piles consisted of cow dung collected one day before the beginning of the experiment from a farm where animals were treated neither with antibiotics nor with antiparasites, avoiding possible toxic effects on the insects associated with dung (Floate 1998). We used $100 \mathrm{ml}$ metallic containers to obtain dung piles of equal shape and size. Piles were $2 \mathrm{~cm}$ high, 8 $\mathrm{cm}$ in diameter with an initial dry weight of $17.6 \pm 0.18 \mathrm{mg}(\mathrm{n}=30$, mean $\pm 1 \mathrm{SE})$. Each fresh dung pile was set up on the ground over a $20 \times 20 \mathrm{~cm}$ plastic mesh $\left(9 \mathrm{~mm}^{2}\right.$ of sieve) to avoid the loss of dung and an eventual overestimation of dung decomposition.

We considered the first $10 \mathrm{~m}$ from the edge toward the interior of the forest or toward the interior of pine plantations as their borders. We also considered as the interior of the continuous forest a place located at least $100 \mathrm{~m}$ from the nearest edge, because the most striking edge effects do not penetrate more than 50-100 m inward (Laurance et al. 2002). In the forest fragments, the dung piles were installed in its geometric center and on the borders.

Groups of three dung piles (1 m apart) were spaced at least $10 \mathrm{~m}$ apart in linear transects on the border and in the interior of each habitat. In total, we distributed 540 dung piles in the experimental area. One of these piles was removed from each group after nine $\left(\mathrm{t}_{1}\right), 30\left(\mathrm{t}_{2}\right)$ and $58\left(\mathrm{t}_{3}\right)$ days after the beginning of the experiment. Following Klein (1989), we used cow dung as experimental substrate. This experimental design used here allows us to compare our results with those of Klein (1989) regarding beetle abundance and dung decomposition in a tropical forest.

\section{Laboratory work}

Beetles were manually removed from the dung piles, preserved in alcohol and identified following taxonomic keys or by comparison with reference collections from the Museo Nacional de Historia Natural, Santiago. After removing all beetle fauna, disintegrated dung piles were dried at $100^{\circ} \mathrm{C}$ for five days and weighted to estimate dung decomposition. Decomposition involves the active or passive remove of dead organic matter, performed by biotic and abiotic agents. Typically, it is measured as weight loss; the usual strategy for assessing weight loss is to set a known quantity of material at a specific location and then periodically evaluate the weight loss (Robertson \& Paul 2000). Consequently, we evaluated dung decomposition as the dry weight loss of the dung piles in every sampling time $\left(\mathrm{t}_{1}, \mathrm{t}_{2}\right.$ and $\left.\mathrm{t}_{3}\right)$. As an initial dry weight, we used the average initial dry weight of 30 intact dung piles.

\section{Data analysis}

We calculated the Morisita's index of similarity and built a phenogram to compare the beetle species assemblages among the six locations: the interior and borders of the three kinds of habitats. This index considers both the species composition and the proportional abundance of the species in each location. The phenogram was built using the UPGMA clustering algorithm (Sneath \& Sokal 1973). The statistical significance of the observed clusters was determined through a randomization test (Manly 1998).

Differences in the number of beetle species, number of individuals and dung decomposition were tested using a two-way repeated measures ANOVA, with habitat (i.e., continuous forest, forest fragments and pine plantations) and location (i.e., interior and border) as the factors and sampling time as the repeated factor. Given that the continuous forest is not replicable, we considered each dung pile as the experimental unit. Species richness, abundance and decomposition rate at contiguous dung pile 
groups are statistically independent at all times $\left(t_{1}-t_{3}\right)$ and settings (border-interior, continuous forest, forest fragments, and pine plantations; Mantel test critical value $>0.105, \mathrm{P}<0.05$ for all cases). Therefore, we can use each dung pile as a legitimate replicate. We used the GreenhouseGeisser adjusted probabilities given that data did not satisfy the sphericity assumption (Scheiner \& Gurevitch 1993). Statistical analyses were done using Statistica (StatSoft, Inc. 2000), and Pop Tools software (Hood 2003).

\section{RESULTS}

\section{The beetle fauna}

We collected 1,730 beetles belonging to 15 families and 36 species, all of them natives. Of these, 832 individuals of 19 species were recorded in the continuous forest, 639 individuals of 16 species in the pine plantations and 259 individuals of 22 species in the forest fragments (Table 1). Staphylinidae was the

\section{TABLE 1}

Total number of beetles found in the continuous forest (CF), pine plantation (PP) and forest fragments

(FF). The trophic level is indicated at family level (Fam): $\mathrm{C}=$ coprophagous, $\mathrm{D}=$ detritivore, $\mathrm{F}=$ fungivore, $\mathrm{H}=$ herbivore, $\mathrm{P}$ = predator (Strong et al. 1984, Borror et al. 1989, Saiz et al. 1989, Lawrence 1991, Lawrence \& Britton 1991, Peña 1992, Artigas 1994)

Número total de coleópteros encontrados en el bosque continuo (CF), plantaciones de pino (PP) y fragmentos de bosque (FF).

Se indica el nivel trófico a nivel de familia $(\mathrm{Fam}): \mathrm{C}=$ coprófago, $\mathrm{D}=$ detritívoro, $\mathrm{F}=$ fungívoro, $\mathrm{H}=$ herbívoro, $\mathrm{P}=$ depredador (Strong et al. 1984, Borror et al. 1989, Saiz et al. 1989, Lawrence 1991, Lawrence \& Britton 1991, Peña 1992, Artigas 1994)

\begin{tabular}{|c|c|c|c|c|c|}
\hline \multirow[t]{2}{*}{ Family } & \multirow[t]{2}{*}{ Species } & \multicolumn{3}{|c|}{ Total number of individuals } & \multirow[b]{2}{*}{ Trophic level } \\
\hline & & $\mathrm{CF}$ & $\mathrm{PP}$ & $\mathrm{FF}$ & \\
\hline Acanthoceridae & Martinezostes asper (Phil.) & 3 & 0 & 0 & Fam: D-F \\
\hline Biphyllidae & Diplocoelus sp. & 0 & 0 & 2 & ¿? \\
\hline Carabidae & Cyanotarus andinus (Germ.) & 0 & 0 & 1 & Fam: P \\
\hline Carabidae & Euproctinus fasciatus (Solier) & 1 & 0 & 0 & Fam: $\mathrm{P}$ \\
\hline Ciidae & Cis sp. & 23 & 0 & 5 & Fam: F \\
\hline Coleoptera & Coleoptera sp.1 & 0 & 1 & 0 & - \\
\hline Coleoptera & Coleoptera sp. 2 & 1 & 3 & 1 & - \\
\hline Crysomelidae & Crysomelidae sp. 1 & 0 & 0 & 7 & Fam: H \\
\hline Crysomelidae & Psathyrocerus sp. & 0 & 0 & 1 & Fam: H \\
\hline Histeridae & Phelister vibius (Marseul) & 1 & 0 & 0 & Fam: D-P \\
\hline Lathridiidae & Aridius sp. & 0 & 1 & 1 & Fam: F \\
\hline Leiodidae & Eupelates sp. & 0 & 0 & 1 & Fam: F-D \\
\hline Leiodidae & Leiodidae sp.1 & 1 & 1 & 0 & Fam: F-D \\
\hline Leiodidae & Leiodidae sp. 2 & 2 & 0 & 0 & Fam: F-D \\
\hline Melyridae & Arthrobachus sp. & 60 & 99 & 25 & Fam: P-H \\
\hline Nitidulidae & Carpophilus sp. & 1 & 0 & 0 & Fam: D \\
\hline Ptiliidae & Acrotrichis chilensis (F. \& G.) & 181 & 86 & 37 & Fam: F \\
\hline Ptinidae & Ptinus sp. 1 & 162 & 46 & 31 & Fam: D \\
\hline Ptinidae & Ptinus sp. 2 & 0 & 0 & 1 & Fam: D \\
\hline Staphylinidae & Atheta obscuripennis (Solier) & 343 & 174 & 41 & Fam: P-C \\
\hline Staphylinidae & Baeocera sp. & 0 & 1 & 0 & Fam: P-C \\
\hline Staphylinidae & Bolitobius unicolor (F. \& G.) & 0 & 1 & 0 & Fam: P-C \\
\hline Staphylinidae & Conosomus sp. 1 & 0 & 1 & 0 & Fam: P-C \\
\hline Staphylinidae & Conosomus sp. 2 & 1 & 0 & 0 & Fam: P-C \\
\hline Staphylinidae & Conosomus sp. 3 & 0 & 1 & 0 & Fam: P-C \\
\hline Staphylinidae & Dasymera sp. & 0 & 70 & 2 & Fam: P-C \\
\hline Staphylinidae & Kainolinus socius (Ful.) & 0 & 0 & 2 & Fam: P-C \\
\hline Staphylinidae & Leptoglossula sculpticollis (Flauvel) & 1 & 0 & 15 & Fam: P-C \\
\hline Staphylinidae & Loncovilius discoideus (F. \& G.) & 1 & 0 & 1 & Fam: P-C \\
\hline Staphylinidae & Omaliopsis russata (F. \& G.) & 0 & 0 & 1 & Fam: P-C \\
\hline Staphylinidae & Plesiomalota merula (Flauvel) & 39 & 21 & 73 & Fam: P-C \\
\hline Staphylinidae & Spanioda spectrum (Flauvel) & 7 & 0 & 1 & Fam: P-C \\
\hline Staphylinidae & Spanioda sp. & 0 & 10 & 0 & Fam: P-C \\
\hline Tenebrionidae & Allecula sp. & 1 & 0 & 0 & Fam: $\mathrm{H}$ \\
\hline Tenebrionidae & Apocrypha sp. & 0 & 0 & 1 & Fam: $\mathrm{H}$ \\
\hline Zopheridae & Namunaria angustata (Solier) & 3 & 123 & 9 & Fam: F \\
\hline \multicolumn{2}{|c|}{ Total number of individuals } & 832 & 639 & 259 & \\
\hline \multicolumn{2}{|c|}{ Total number of species } & 19 & 16 & 22 & \\
\hline
\end{tabular}


most speciose family (13 species), whereas the other families were represented by only one to three species (Table 1). The most abundant families (i.e., with species with more than 40 individuals) were Staphylinidae, Ptiliidae, Ptinidae, Zopheridae and Melyridae. Two of these families, Staphylinidae and Ptiliidae, were more abundant at $t_{1}$, decreasing progressively until their disappearance at $t_{3}$. Ptinidae, Zopheridae and Melyridae presented the opposite trend, with scarce or no abundance at $\mathrm{t}_{1}$ but increasing numbers through time.

\section{Species similarity and species richness of beetles}

Beetle assemblages were statistically dissimilar only on the borders of both of the continuous forest and pine plantations (Fig. 1). These differences were accounted for two species that dominated each one of these habitats. Ptinus sp. 1 was nine times more abundant on the border of the continuous forest than its average abundance in all other habitats, while $N$. angustata was 7.5 times more abundant in the border of the pine plantations.

Species richness (number of species $\mathrm{mg}^{-1}$ of dry dung) varied through habitat and time. At $\mathrm{t}_{1}$, species richness was 2.5 times higher in the continuous forest than in the forest fragments $(0.15 \pm 0.01$ versus $0.06 \pm 0.01$ species; mean \pm $1 \mathrm{SE})$, whereas pine plantations had an intermediate species richness $(0.11 \pm 0.01$ species; mean $\pm 1 \mathrm{SE}$ ). These differences disappeared over time (Fig. 2). Species richness was statistically similar in the edges and interior of the three habitats (Table 2).

\section{Abundance of beetles}

The highest number of individuals occurred after nine days $\left(\mathrm{t}_{1}\right)$. At $\mathrm{t}_{1}$, the most abundant species were Atheta obscuripennis $(\mathrm{n}=539)$

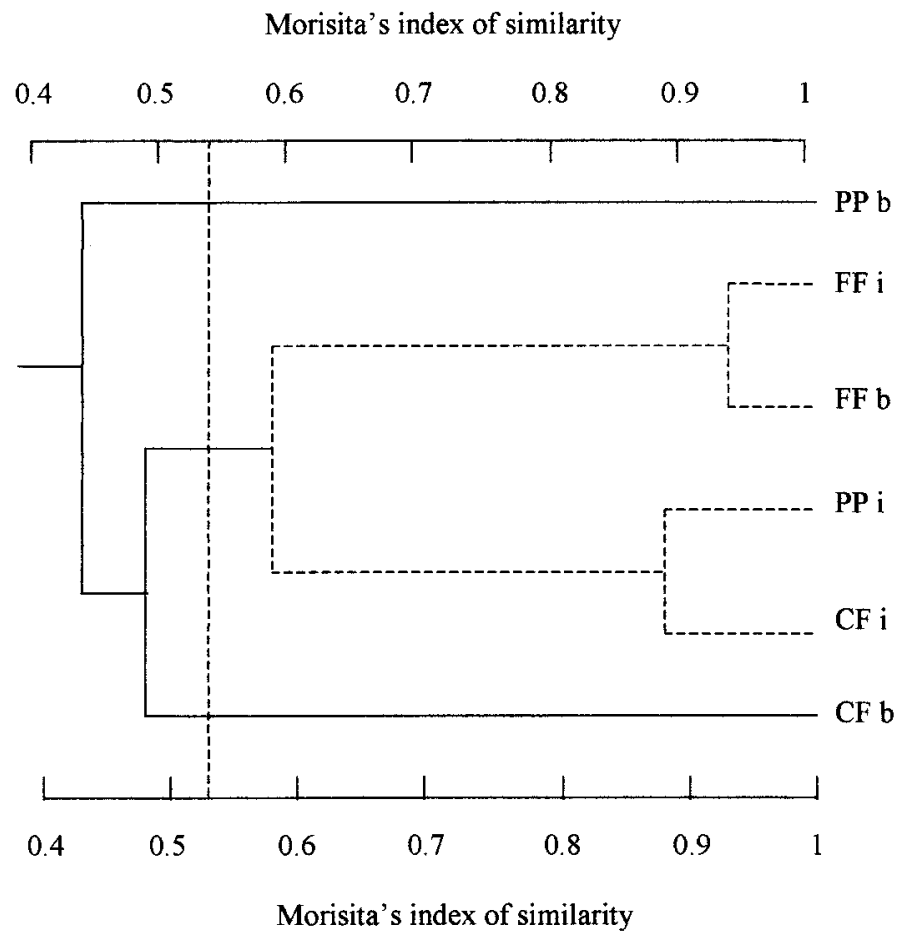

Fig. 1: Phenogram resulting from application of UPGMA clustering algorithm (Sneath \& Sokal 1973 ) to the similitary values of Morisita's index among the six locations (CF $=$ continuous forest, $\mathrm{PP}=$ pine plantations and $\mathrm{FF}=$ forest fragments, $\mathrm{b}=$ border, $\mathrm{i}=$ interior $)$. The perpendicular dotted line on the similarity axis represents the critical value (for $\alpha=0.05$ ) obtained from the null distribution ( $\mathrm{n}=15,000$ iterations).

Dendrograma resultante de la aplicación del algoritmo de agrupación UPGMA (Sneath \& Sokal 1973) a los valores de similitud calculados con el índice de Morisita entre los seis sitios $(\mathrm{CF}=$ bosque continuo, $\mathrm{PP}=$ plantaciones de pino, $\mathrm{FF}=$ fragmentos de bosque, $\mathrm{b}=$ borde y $\mathrm{i}=$ centro). La línea punteada perpendicular a eje de similitud representa el valor crítico (para un $\alpha=0,05)$ obtenido a partir de la distribución nula $(\mathrm{n}=15.000$ iteraciones). 
$t_{1}(9$ days $)$

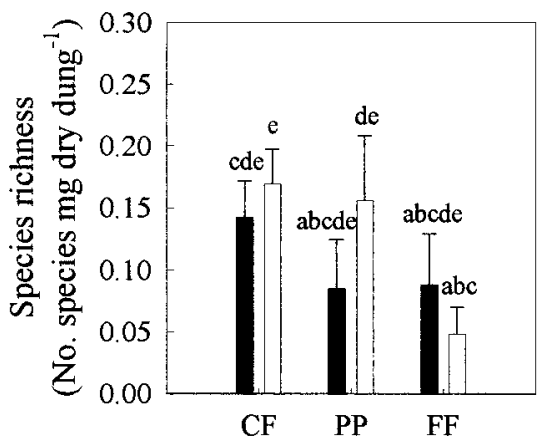

$t_{2}$ (30 days)

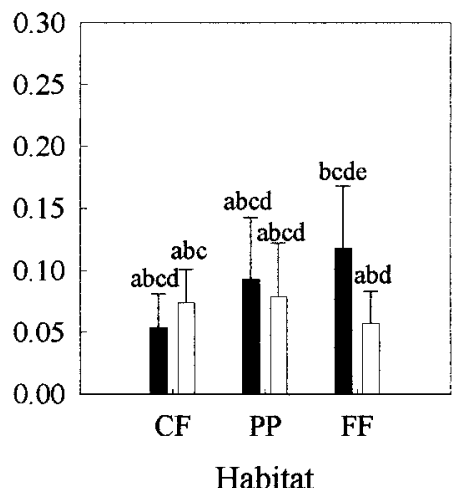

$t_{3}$ (58 days)

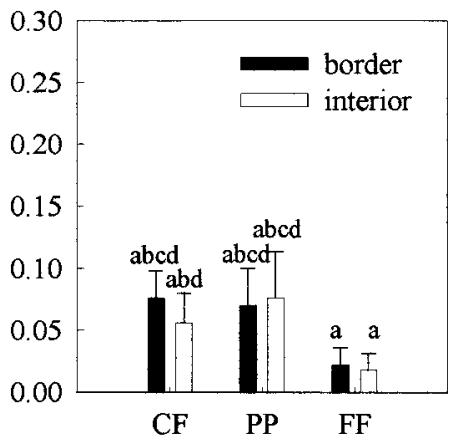

Fig. 2: Species richness of beetles associated with dung on the border and interior of each habitat in every sampling time (mean $\pm 1 \mathrm{SE})$. Different letters represent significant statistical differences $(\mathrm{P}$ $<0.05)(\mathrm{CF}=$ continuous forest, $\mathrm{PP}=$ pine plantations, and $\mathrm{FF}=$ forest fragments $)$.

Riqueza de especies de coleópteros asociados a las heces en los bordes y centros de cada hábitat para cada una de las fechas de muestreo (media $\pm 1 \mathrm{EE})$. Letras distintas representan diferencias estadísticamente significativas $(\mathrm{P}<0,05)(\mathrm{CF}$ = bosque continuo, $\mathrm{PP}=$ plantaciones de pino y $\mathrm{FF}=$ fragmentos de bosque) .

\section{TABLE 2}

Results of repeated measures ANOVA for the effect of habitat (continuous forest, forest fragments and pine plantations), location within each habitat (border, interior) and sampling time (9,30 and

58 days) on beetle species richness (number of species /mg of dry dung). Letter $\mathrm{P}^{*}$ is the non adjusted probability, $\mathrm{P}$ adj. is the adjusted probability based on the epsilon value of the

\section{Greenhouse-Geisser estimator}

Resultados del ANDEVA de medidas repetidas para el efecto del hábitat (bosque continuo, fragmentos de bosque y plantaciones de pino), ubicación dentro de cada hábitat (borde, centro) y fecha de muestreo ( 9,30 y 58 días) sobre la riqueza de especies de coleópteros (número de especies/mg de hez seca). $\mathrm{P}^{*}$ corresponde a la probabilidad no ajustada, $\mathrm{P}$ adj. es la probabilidad ajustada basada en el valor de epsilon del estimador Greenhouse-Geisser

\begin{tabular}{|c|c|c|c|c|c|}
\hline Source of variation & Degree of freedom & Mean square & F-value & $\mathrm{P}^{*}$-value & $P$ adj-value \\
\hline Habitat & 2 & 0.07 & 7.62 & $<0.01$ & \\
\hline Location & 1 & 0.00 & 0.04 & 0.84 & \\
\hline Habitat*location & 2 & 0.04 & 3.87 & 0.02 & \\
\hline Error & 170 & 0.01 & & & \\
\hline Sampling time & 2 & 0.17 & 20.98 & $<0.01$ & $<0.01$ \\
\hline Habitat*sampling time & 4 & 0.05 & 6.18 & $<0.01$ & $<0.01$ \\
\hline Location*sampling time & 2 & 0.02 & 1.97 & 0.14 & 0.14 \\
\hline Habitat*location*sampling time & 4 & 0.02 & 2.12 & 0.07 & 0.08 \\
\hline Error & 340 & 0.01 & & & \\
\hline
\end{tabular}

Greenhouse-Geisser e $=0.903$

and Acrotrichis chilensis $(\mathrm{n}=276)$, which accounted for $87 \%$ of the 933 individuals collected. At $\mathrm{t}_{2}$, the most abundant species were Plesiomalota merula $(\mathrm{n}=99)$, Arthrobrachus sp. $(\mathrm{n}=95)$, Namunaria angustata $(\mathrm{n}=76)$ and Dasymera $\mathrm{sp} .(\mathrm{n}=53)$, which accounted for $75 \%$ of the 429 individuals. At $t_{3}$, the most abundant species were Ptinus sp. $1(\mathrm{n}=194)$, Arthrobrachus sp. $(\mathrm{n}=89)$ and $N$. angustata $(\mathrm{n}=52)$ being $91 \%$ of the 368 individuals.

Abundance (number of beetles mg dry dung1) was significantly higher in the continuous forest than in the pine plantations and forest 
fragments; however, this pattern varied through time (Table 3). At $t_{1}$, abundance in the continuous forest was three and six times higher than in the pine plantations and forest fragments, respectively $(0.90 \pm 0.12$ versus $0.34 \pm 0.10$ and $0.14 \pm 0.02$ beetles mg dry dung $^{-1}$, mean $\pm 1 \mathrm{SE}$ ). At $t_{3}$, abundance in the continuous forest was 16 times higher than in the forest fragments $(0.48 \pm 0.12$ versus $0.03 \pm$ 0.01 beetles mg dry dung $^{-1}$, mean $\left.\pm 1 \mathrm{SE}\right)$, whereas the abundance at the pine plantations was intermediate $(0.16 \pm 0.04$ beetles, mean \pm 1 $\mathrm{SE})$. Nevertheless, at $\mathrm{t}_{2}$, abundance was similar among habitats (Table 3, Fig. 3).

TABLE 3

Results of repeated measures ANOVA for the effect of habitat (continuous forest, forest fragments and pine plantations), location within each habitat (border, interior) and sampling time $(9,30$ and

58 days) on beetle abundance (number of individuals/mg of dry dung). Letter $\mathrm{P}^{*}$ is the non adjusted probability, $\mathrm{P}$ adj. is the adjusted probability based on the epsilon value of the

\section{Greenhouse-Geisser estimator}

Resultados del ANDEVA de medidas repetidas para el efecto del hábitat (bosque continuo, fragmentos de bosque y plantaciones de pino), ubicación dentro de cada hábitat (borde, centro) y fecha de muestreo (9, 30 y 58 días), sobre la abundancia de coleópteros (número de individuos/mg de hez seca). El valor de $\mathrm{P} *$ indica la probabilidad no ajustada, P adj., es la probabilidad ajustada basada en el valor de epsilon del estimador Greenhouse-Geisser

\begin{tabular}{|c|c|c|c|c|c|}
\hline Source of variation & Degree of freedom & Mean square & F-value & $\mathrm{P}^{*}$-value & $P$ adj-value \\
\hline Habitat & 2 & 8.06 & 22.48 & $<0.01$ & \\
\hline Location & 1 & 0.02 & 0.07 & 0.78 & \\
\hline Habitat*location & 2 & 0.41 & 1.16 & 0.31 & \\
\hline Error & 170 & 0.35 & & & \\
\hline Sampling time & 2 & 4.32 & 13.14 & $<0.01$ & $<0.01$ \\
\hline Habitat*sampling time & 4 & 2.87 & 8.72 & $<0.01$ & $<0.01$ \\
\hline Location*sampling time & 2 & 5.01 & 15.23 & $<0.01$ & $<0.01$ \\
\hline Habitat*location*sampling time & 4 & 2.21 & 6.72 & $<0.01$ & $<0.01$ \\
\hline Error & 340 & 0.32 & & & \\
\hline
\end{tabular}

Greenhouse-Geisser e $=0.952$

$\mathrm{t}_{1}$ ( 9 days)

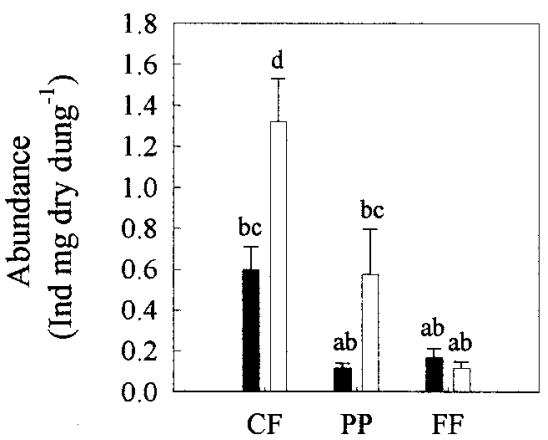

$t_{2}$ (30 days)

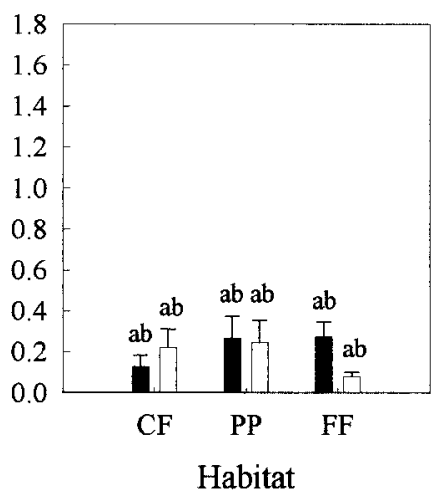

$t_{3}$ (58 days)

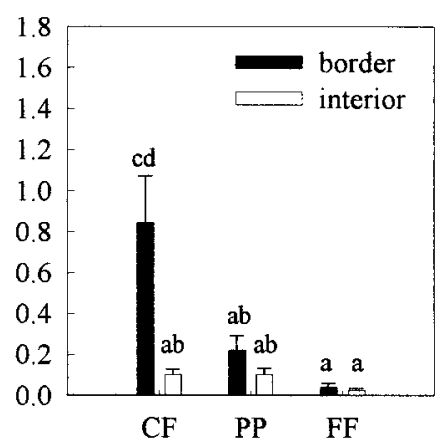

Fig. 3: Abundance of beetles associated with dung on the border and interior of each habitat in every sampling time (mean $\pm 1 \mathrm{SE})$. Different letters represent significant statistical differences $(\mathrm{P}$ $<0.05)(\mathrm{CF}=$ continuous forest, $\mathrm{PP}=$ pine plantations, and $\mathrm{FF}=$ forest fragments $)$.

Abundancia de coleópteros asociados a las heces en los bordes y centros de cada hábitat para cada una de las fechas de muestreo (media $\pm 1 \mathrm{EE}$ ). Letras distintas representan diferencias estadísticamente significativas $(\mathrm{P}<0,05)(\mathrm{CF}=$ bosque continuo, $\mathrm{PP}=$ plantaciones de pino y $\mathrm{FF}=$ fragmentos de bosque). 
Regarding edge effects, after nine days $\left(t_{1}\right)$, beetles were twice more abundant in the interior than in the border of the continuous forest, whereas at $t_{3}$, they were eight times more abundant on the border. In none of the sampling time, there was an edge effect upon total beetles abundance in the forest fragments and pine plantations (Fig. 3).

Abundance of the five most frequent families was significantly different among habitats (Table 4). Four of these families were more abundant in the continuous forest than in the forest fragments, while one of them (Zopheridae) was more abundant in the pine plantations than in the other two habitats (Fig. 4). There was an edge effect in the abundance of two families: Staphylinidae $\left(\mathrm{t}_{1}\right)$ had more individuals in the interior of the continuous forest and pine plantations, whereas Ptinidae $\left(t_{3}\right)$ was more abundant on the border of the continuous forest (Fig. 4, Table 4).

\section{Dung decomposition}

Dung decomposition did not differ significantly among the three habitats (Table 5). Additionally, decomposition did not differ between the interior and border of the forest fragments and pine plantations, but in the continuous forest, dung decomposition was 2.3 and 1.8 times higher in the border than in the interior at $t_{2}$ and $t_{3}$, respectively (Fig. 5).

\section{DISCUSSION}

Forest fragmentation generally has profound effects upon the composition, structure and functioning of biodiversity (Didham et al. 1996, Chapin et al. 2000). Although in the Maulino forest, species richness and abundance were depressed in the forest fragments, the structure of beetle assemblages only changed in the borders of both the continuous forest and pine plantations, and dung decomposition did not change across the fragmented landscape, except between the border and the interior of the continuous forest. Thus, although the beetle assemblage varies across the fragmented landscape, these changes do not translate into alterations of an ecosystem process such as dung-decomposition, as occurs in tropical forests (Klein 1989).

The differences in the beetle assemblages on the borders of the continuous forest and pine plantations are accounted for the increase in the abundance of only two species, Ptinus sp. 1 (Ptinidae) and $N$. angustata (Zopheridae). Most of the species of Ptinidae are detritivores, and Zopheridae are fungivores (Table 1). Thus, the increased abundance of these species on the borders of these habitats may have some effects upon important ecological processes associated with decomposition. However, little is known about the natural history of insects in Chile, and nothing is known about the specific

TABLE 4

Results of repeated measures ANOVA for the effect of habitat (continuous forest, forest fragments and pine plantations), location within each habitat (border, interior) and sampling time

(9, 30 and 58 days) on the abundance of the most frequent beetle families

Resultados del ANDEVA de medidas repetidas para el efecto del hábitat (bosque continuo, fragmentos de bosque y plantaciones de pino), ubicación dentro de cada hábitat (borde, centro) y fecha de muestreo (9, 30 y 58 días), sobre la abundancia de las cinco familias de coleópteros más numerosas

\begin{tabular}{|c|c|c|c|c|c|c|c|c|c|c|c|}
\hline \multirow{2}{*}{$\begin{array}{l}\text { Family } \\
\text { Source of variation }\end{array}$} & \multirow[b]{2}{*}{ df } & \multicolumn{2}{|c|}{ Melyridae } & \multicolumn{2}{|c|}{ Zopheridae } & \multicolumn{2}{|c|}{ Ptiliidae } & \multicolumn{2}{|c|}{ Ptinidae } & \multicolumn{2}{|c|}{ Staphylinidae } \\
\hline & & MS & $\mathrm{F}$ & MS & $\mathrm{F}$ & MS & $\mathrm{F}$ & MS & $\mathrm{F}$ & MS & $\mathrm{F}$ \\
\hline Habitat & 2 & 0.02 & $3.36^{*}$ & 0.23 & $10.21^{* *}$ & 0.36 & $5.05^{*}$ & 0.21 & $5.85^{* *}$ & 0.72 & $3.21 *$ \\
\hline Location & 1 & 0.02 & 3.41 & 0.03 & 1.53 & 0.16 & 2.25 & 0.29 & $8.14 * *$ & 2.12 & $9.43^{* *}$ \\
\hline Habitat*location & 2 & 0.05 & $9.75^{* *}$ & 0.04 & 2.02 & 0.10 & 1.46 & 0.34 & $9.49 * *$ & 1.08 & $4.82 * *$ \\
\hline Error & 170 & 0.01 & & 0.02 & & 0.07 & & 0.04 & & 0.22 & \\
\hline Sampling time & 2 & 0.07 & $16.01 * *$ & 0.07 & $4.47 *$ & 1.43 & $20.22 * *$ & 0.43 & $11.41 * *$ & 4.86 & $19.63 * *$ \\
\hline Habitat*sampling time & 4 & 0.03 & $5.77 * *$ & 0.05 & 2.92 & 0.46 & $6.41 * *$ & 0.28 & $7.26^{* *}$ & 0.62 & $2.49 *$ \\
\hline Location*sampling time & 2 & 0.00 & 0.04 & 0.03 & 1.69 & 0.38 & $5.48^{*}$ & 0.20 & $5.33 * *$ & 2.65 & $10.71 * *$ \\
\hline Habitat*location*sampling time & 4 & 0.00 & 0.73 & 0.03 & 1.69 & 0.09 & 1.36 & 0.38 & $9.89 * *$ & 0.53 & 2.14 \\
\hline Error & 340 & 0.00 & & 0.02 & & 0.07 & & 0.04 & & 0.25 & \\
\hline
\end{tabular}

$* \mathrm{P}<0.05 ; * * \mathrm{P}<0.01$; adjusted probabilities based on the epsilon value of the Greenhouse-Geisser estimator 

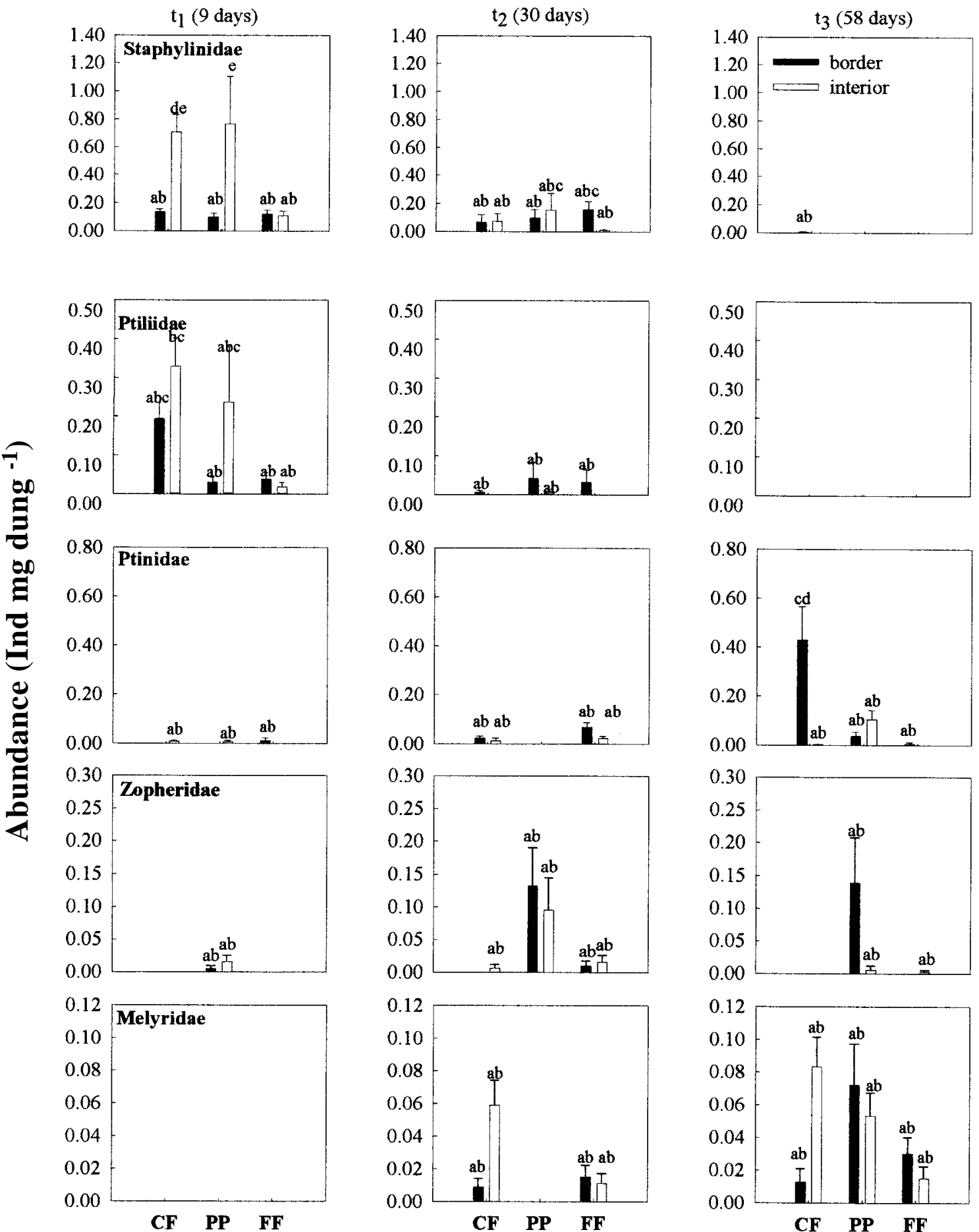

\section{Habitat}

Fig. 4: The most abundant families of beetles associated with dung, on the border and interior of each habitat in every sampling time (mean $\pm 1 \mathrm{SE}$ ). Different letters represent significant statistical differences $(\mathrm{P}<0.05)(\mathrm{CF}=$ continuous forest, $\mathrm{PP}=$ pine plantations, and $\mathrm{FF}=$ forest fragments $)$.

Familias más abundantes de coleópteros asociados a las heces, en los bordes y centros de cada hábitat en cada fecha de muestreo (media $\pm 1 \mathrm{EE}$ ). Letras distintas representan diferencias estadísticamente significativas $(\mathrm{P}<0,05)(\mathrm{CF}=$ bosque continuo, $\mathrm{PP}=$ plantaciones de pino y $\mathrm{FF}=$ fragmentos de bosque). 


\section{TABLE 5}

Results of repeated measures ANOVA for the effect of habitat (continuous forest, forest fragments and pine plantations), location (borders and interiors) and sampling time (9, 30 and 58 days) on dung decomposition (\% weight loss). Letter $\mathrm{P} *$ is the non adjusted probability, $\mathrm{P}$ adj. is the adjusted probability based on the epsilon value of the Greenhouse-Geisser estimator

Resultados del ANDEVA de medidas repetidas para el efecto de el hábitat (bosque continuo, fragmentos de bosque y plantaciones de pino), ubicación dentro de cada hábitat (borde, centro) y fecha de muestreo (9, 30 y 58 días), sobre la descomposición de heces (\% de peso perdido). El valor de $\mathrm{P} *$ corresponde a la probabilidad no ajustada, P adj., es la probabilidad ajustada basada en el valor de epsilon del estimador Greenhouse-Geisser

\begin{tabular}{|c|c|c|c|c|c|}
\hline Source of variation & Degree of freedom & Mean square & F-value & $\mathrm{P} *$-value & $P$ adj-value \\
\hline Habitat & 2 & 4.9 & 0.59 & 0.55 & \\
\hline Location & 1 & 64.9 & 7.92 & 0.01 & \\
\hline Habitat*location & 2 & 251.9 & 30.73 & $<0.01$ & \\
\hline Error & 171 & 8.5 & & & \\
\hline Sampling time & 2 & 20.4 & 4.51 & 0.01 & 0.01 \\
\hline Habitat*sampling time & 4 & 13.1 & 2.91 & 0.02 & 0.03 \\
\hline Location*sampling time & 2 & 47.4 & 10.51 & $<0.01$ & $<0.01$ \\
\hline Habitat*location*sampling time & 4 & 6.3 & 1.40 & 0.23 & 0.20 \\
\hline Error & 342 & 4.5 & & & \\
\hline
\end{tabular}

Greenhouse-Geisser e $=0.988$

$t_{1}$ (9 days)

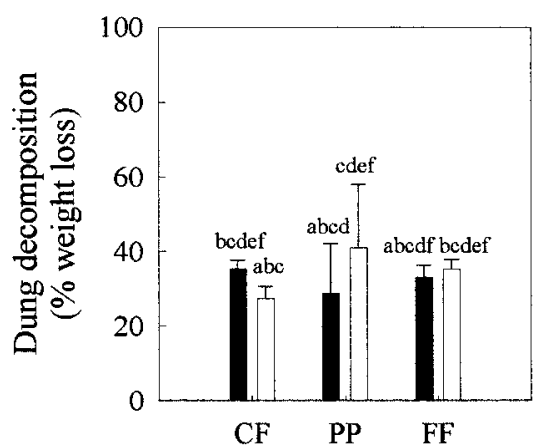

$t_{2}$ (30 days)

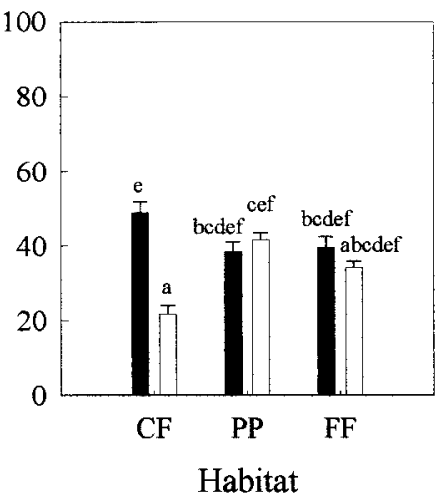

$\mathrm{t}_{3}$ (58 days)

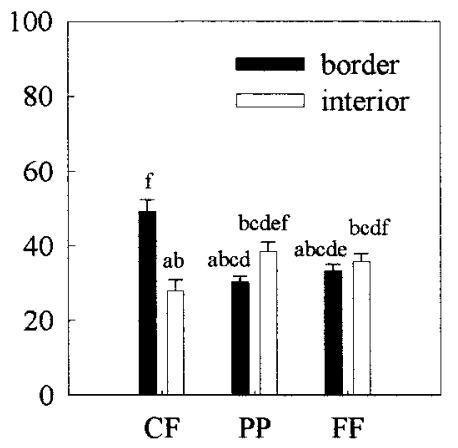

Fig. 5: Dung decomposition (\% weight loss) on the border and interior of each habitat in every sampling time (mean $\pm 1 \mathrm{SE})$. Different letters represent significant statistical differences $(\mathrm{P}<$ $0.05)(\mathrm{CF}=$ continuous forest, $\mathrm{PP}=$ pine plantations, and $\mathrm{FF}=$ forest fragments $)$.

Descomposición de heces ( $\%$ de peso perdido) en los bordes y centros de cada hábitat para cada fecha de muestreo (media $\pm 1 \mathrm{EE})$. Letras distintas representan diferencias estadísticamente significativas $(\mathrm{P}<0,05)(\mathrm{CF}=$ bosque continuo, $\mathrm{PP}=$ plantaciones de pino y $\mathrm{FF}=$ fragmentos de bosque).

biology of these two species. The paucity of this kind of knowledge is regarded as one of the major threats to biodiversity conservation in South America (Mares 1992, Barbosa \& Marquet 2002) and makes it difficult to explain the possible consequences of these changes in beetle assemblages upon ecosystem processes.
Contrary to our initial prediction, species richness and abundance of dung beetles were depressed in the Maulino forest fragments, in agreement with the effects observed in tropical forests. Notwithstanding, the mechanisms explaining these effects seem to be different. In tropical forests, this decrease is associated with 
the reduction in the availability of dung, brought about by the reduced richness and abundance of large herbivores (Klein 1989, Andresen 2003). In the Maulino forest, the dwarf deer, Pudu pudu, which is probably the only large herbivore in this forest, is more abundant in the forest fragments than in the continuous forest (Donoso et al. 2003). Therefore, dung availability might not account for changes in the dung-associated beetle assemblages. Possibly, the observed reductions could be due to the increased abundance of insectivores such as carabid beetles, ground foraging birds and small mammals in the forest fragments, which could be exerting a higher predation pressure upon this insect assemblage (Grez in press, Saavedra \& Simonetti in press, Vergara \& Simonetti in press).

The abundance of different species varied across the fragmented landscape. For instance, A. chilensis was more abundant in the continuous forest and pine plantations than in the forest fragments, whereas $N$. angustata was more abundant in the pine plantations, being almost nil its abundance in the continuous forest. Furthermore, these patterns change over time illustrating the temporal dynamics associated to succession process of the beetles on dung. Changes in species composition through time could result from changing availability of resources, brought about by biotic and abiotic agents or by seasonal variation in the number of individuals of the different species involved in the succession (Mohr 1943, Packham et al. 1992). Thus, changes in the dung wetness, odor, availability of soluble nutrients, chemical properties or bacteriological, among others, are some of the possible reasons of the observed succession. Species with coprophagous habits are more probable to be found in the earlier states of a succession process, while in the later states, predator o more generalist species are usually found (Mohr 1943, Lobo 1992). The interpretation of these specific and dynamic responses need a more advanced knowledge of the trophic habits of the species implicated since we only have information at family level (Table 1), a fact that further stresses the need for natural history information.

Edge effect may be remnant size-related (Laurance et al. 2002). While in forest fragments no edge effect was evident, in the continuous forest the abundance and dung decomposition differed between the interior and border of this habitat, similar to what occurs with granivory, suggesting that these small fragments might lack true interior or "core" habitat for beetles as well as for other organisms and processes (Donoso et al. 2003).

Pine plantations surrounding the Maulino forest hold a totally native beetle assemblage associated with dung although depressed compared to the continuous forest. In addition, dung decomposition in this habitat was similar to decomposition in both continuous and forest fragments. Litterfall decomposition can be even higher in pine plantations than in native forest (Lusk et al. 2001). So, contrary to a widelyheld assumption that matrices are unsuitable habitats for original biota and the ecological processes involved, these pine plantations seem to maintain at least in part the structural and functional biodiversity, connecting the native remnants throughout the landscape, a crucial factor in biodiversity conservation (Simonetti et al. 2003).

When comparing tropical and temperate fragmented forest and searching for association between beetle community and dung decomposition, we found that the alteration of the coleopteran assemblage has different consequences on dung decomposition. In our study, after nine days, despite the large species richness and abundance of beetles associated with dung in the continuous forest in comparison with the forest fragments, dung decomposition remained the same in both habitats. In tropical forests, the higher abundance and species richness of beetles in the continuous forest were associated with higher dung decomposition (Fig. $6 \mathrm{~A}$ and 6B). Consequently, a decrease in the species richness or in the abundance of beetles in the temperate forest fragments has little or none effect on dung decomposition. This difference may be explained largely by the nature of the fauna involved in the decomposition process in both ecosystems. In the tropics, decomposition is accounted for a very rich beetle assemblage composed primarily by Scarabaeidae (Halffter \& Edmonds 1982). For instance, Klein (1989) and Andresen (2003), in studies done in Brazil, found 55 and 58 species of Scarabaeidae in their study sites respectively. In Chile, only seven species of coprophagous Scarabaeidae are known, from which four of them could occur at the Maulino forest according to their geographic distribution (Joseph 1929, Gutierrez 1940, Ovalle \& Solervicens 1980, Saíz et al. 1989, Peña 1992). However, only one of them -(Dichotomius torulosus Esch.)- was observed (although not collected) at our study site. In addition, the absence of association between dung decomposition and beetle fauna at the Maulino forest could emerge from the fact that the 
(A)

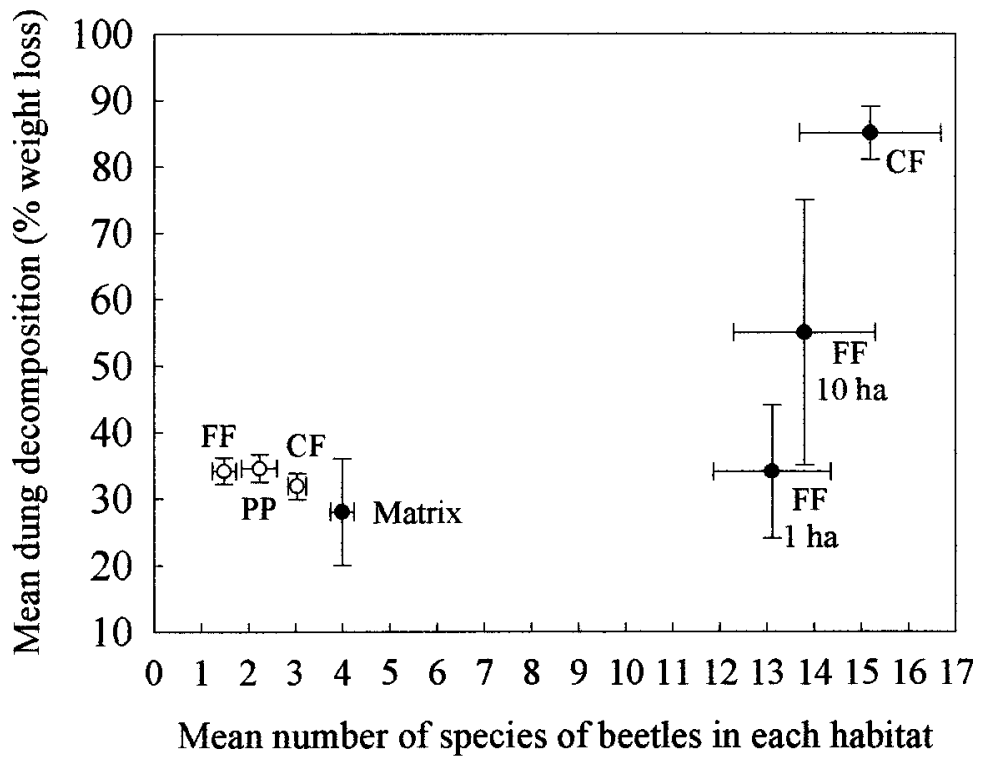

(B)

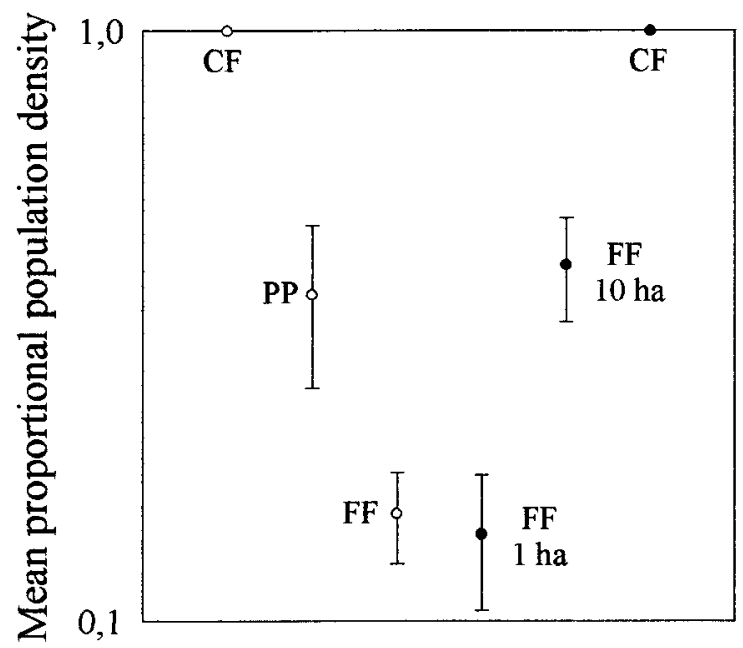

Fig. 6: Comparison of beetles associated with dung and dung decomposition between temperate and tropical fragmented forests. Open dots are from temperate forest (this study) and full dots are from tropical forest (Klein 1989). (A) Mean percentage of dung decomposition (\% weight loss) as a function of mean richness of beetles associated with dung; (B) mean proportional population density of beetles in each habitat ( $\mathrm{CF}=$ continuous forest, $\mathrm{PP}=$ pine plantations, and $\mathrm{FF}=$ forest fragments).

Comparación del ensamble de coleópteros asociados a heces y de la descomposición en bosques fragmentados templados y tropicales. Los círculos vacíos corresponden a bosques templados (este estudio) y los círculos llenos a bosques tropicales (Klein 1989). (A) Porcentaje medio de descomposición de heces (\% de peso perdido) en función de la riqueza media de especies de coleópteros asociados a ellas; (B) media de la densidad poblacional proporcional de coleópteros en cada hábitat $(\mathrm{CF}=$ bosque continuo, $\mathrm{FF}=$ fragmentos de bosque y $\mathrm{PP}=$ plantaciones de pino $)$. 
contribution of these beetles to dung decomposition is lower than beetles in the tropical forest. Again, detailed information regarding habits of Chilean insects is badly needed to unravel the effects of habitat transformation upon compositional, structural and functional biodiversity at the Maulino forest. In summary, despite changes in richness and abundance of beetle assemblages associated with dung in a fragmented Maulino forest, the decomposition process remains unaltered, so functional biodiversity is still conserved.

\section{ACKNOWLEDGMENTS}

This study is part of the Undergraduate Thesis of MA Bustamante-Sánchez. We are grateful to G. Arriagada for his assistance in the identification of beetles, to JL Celis, A Gallardo, R Jaña and D Larrea for their help with fieldwork. This study was supported by FONDECYT 1010852.

\section{LITERATURE CITED}

ANDRESEN E (2003) Effect of forest fragmentation on dung beetle communities and functional consequences for plant regeneration. Ecography 26: 87-97.

ARTIGAS JN (1994) Entomología económica. Segundo volumen. Ediciones de la Universidad de Concepción, Concepción, Chile. 943 pp.

BARBOSA O \& PA MARQUET (2002) Effects of forest fragmentation on the beetle assemblage at the relict forest of Fray Jorge, Chile. Oecologia 132: 296-306.

BORROR D, CH TRIPHLEHORN \& N JOHNSON (1989) An introduction of the study of insects. Sixth edition. Saunders College Publishing, Philadelphia, Pennsylvania, USA. 875 pp.

BUSTAMANTE RO \& C CASTOR (1998) The decline of an endangered temperate ecosystem: the ruil (Nothofagus alessandrii) forest in central Chile. Biodiversity and Conservation 7: 1607-1626.

CHAPIN III FS, ES ZAVALETA, VT EVINER, RL NAYLOR, PM VITOUSEK, HL REYNOLDS, DU HOOPER, S LAVOREL, OE SALA, SE HOBBIE, MC MARCK \& S DÍAZ (2000) Consequences of changing biodiversity. Nature 405: 234-242.

DIDHAM RK, J GHAZOUL, NE STORK \& AJ DAVIS (1996) Insects in fragmented forest: a functional approach. Trends in Ecology and Evolution 11: 255-260.

DIDHAM RK, PM HAMMOND, JH LAWTON, P EGGLETON \& NE STORK (1998) Beetles species responses to tropical forest fragmentation. Ecological Monographs 68: 295-323.

DONOSO D, AA GREZ \& JA SIMONETTI (2003) Effects of forest fragmentation on the granivory of differently sized seeds. Biological Conservation 115: 63-70.

ESTRADA A (2002) Dung beetles in continuous forest, forest fragments and in an agricultural mosaic habitat island at Los Tuxtlas, Mexico. Biodiversity and Conservation 11: 1903-1918.

FLOATE KD (1998) Off-target effects of ivermectin on insects and on dung degradation in southern Alberta, Canada. Bulletin of Entomological Research 88: 25-35.

GOLDEN DM \& TO CRIST (2000) Experimental effects of habitat fragmentation on rove beetles and ants: patch or edge? Oikos 90: 525-538.

GREZ AA, RO BUSTAMANTE, JA SIMONETTI \& L FAHRIG (1998) Landscape ecology, deforestation, and forest fragmentation: the case of the ruil forest in Chile. In: Salinas-Chávez E \& J Middleton (eds) Landscape ecology as a tool for sustainable development in Latin America. http://www.brocku.ca/ epi/lebk/grez.html.

GREZ AA (in press) El valor de los fragmentos pequeños de bosque Maulino en la conservación de la fauna de coleópteros epígeos. In: Smith-Ramírez C, J Armesto \& C Valdovinos (eds) Biodiversidad y ecología de los bosques de la cordillera de la Costa de Chile. Editorial Universitaria, Santiago, Chile.

GUTIÉRREZ R (1940) Contribuciones al estudio de Scarabaeidae chilenos. Revista Chilena de Historia Natural 44: 93-99; 275-280.

HALFFTER G \& WD EDMONDS (1982) The nesting behavior of dung beetles (Scarabaeinae): an ecological and evolutive approach. Instituto de Ecología, México Distrito Federal, México. 176 pp.

HOOD GM (2003) Pop Tools version 2.5.8. Available in internet. URL http://www.cse.csiro.au/poptools.

JOSEPH HC (1929) El Pinotus torulosus Eschscholtz. Revista Chilena de Historia Natural 33: 31-46.

KLEIN BC (1989) Effects of forest fragmentation on dung and carrion beetle communities in central Amazonia. Ecology 70: 1715-1725.

LARA A, C DONOSO \& JC ARAVENA (1996) La conservación del bosque nativo en Chile: problemas y desafíos. In: Armesto JJ, C Villagrán \& MTK Arroyo (eds) Ecología de los bosques nativos de Chile: 335-362. Editorial Universitaria, Santiago, Chile.

LAURENCE WF, TE LOVEJOY, HL VASCONCELOS, EM BRUNA, RK DIDHAM, PC STOUFFER, C GASCON, RO BIERREGAARD, SG LAURENCE \& AE SAMPAIO (2002) Ecosystem decay of Amazonian forest fragments: a 22 year investigation. Conservation Biology 16: 605-618.

LAWRENCE JF (1991) Order Coleoptera. In: Stehr FW (ed) Immature insects. Volume 2: 144-658. Kendall/Hunt, Dubuque, Iowa, USA.

LAWRENCE JF \& EB BRITTON (1991) Coleoptera (Beetles). In: CSIRO Division of Entomology (ed) The insects of Australia: a text book for students and research workers. Second edition, Volume 2: 543-638. Cornell University Press, Ithaca, New Cork, USA.

LOBO JM (1992) Microsucesión de insectos en heces de vacuno: influencia de las condiciones ambientales y relaciones entre grupos tróficos. Graellsia 48: 71-85.

LUSK CH, C DONOSO, M JIMÉNEZ, C MOYA, G OYARCE, R REINOSO, A SALDAÑA, P VILLEGAS \& F MATUS (2001) Descomposición de hojarasca de Pinus radiata y tres especies arbóreas nativas. Revista Chilena de Historia Natural 74: 705-710.

MANLY BFJ (2001) Randomization, bootstrap and Montecarlo methods in biology. Second edition. Chapman \& Hall, London, United Kingdom. Xxxii $+424 \mathrm{pp}$.

MARES MA (1992) Conservation in South America: problems, consequences and solutions. Science 233: 734-739. 
MOHR CO (1943) Cattle droppings as ecological units. Ecological Monographs 13: 2778-298.

OVALLE M \& J SOLERVICENS (1980) Observaciones sobre la biología de Megathopa villosa Escholtz, 1822 (Coleoptera, Scarabaeidae, Scarabaeinae). Boletín del Museo Nacional de Historia Natural (Chile) $37: 235-246$.

PACKHAM JR, DJL HARDING, GM HILTON \& RA STUTTARD (1992) Functional ecology of woodlands and forests. Chapman \& Hall, London, United Kingdom. 384 pp.

PEÑA LE (1992) Introducción al estudio de los insectos de Chile. Editorial Universitaria, Santiago, Chile. $253 \mathrm{pp}$.

PETERSEN H \& M LUXTON (1982) A comparative analysis of soil fauna populations and their role in decomposition process. Oikos 39: 287-388.

ROBERTSON GP \& EA PAUL (2000) Decomposition and soil organic matter dynamics. In: Sala OE, RB Jackson, HA Mooney \& RW Howarth (eds) Methods in ecosystem science: 104-116. Springer, New Cork, New York, USA.

SAAVEDRA B \& JA SIMONETTI (in press) Micromamíferos asociados a fragmentos de bosque Maulino y plantaciones de pino aledañas. In: SmithRamírez C, JJ Armesto \& C Valdovinos (eds) Bosques de la cordillera de la Costa: historia, biodiversidad y ecología. Editorial Universitaria, Santiago, Chile.

SAIZ F, J SOLERVICENS \& P OJEDA (1989) Coleópteros del Parque Nacional La Campana y Chile central. Ediciones Universitarias de Valparaíso, Valparaíso, Chile. 124 pp.

SALA EO, FS CHAPIN III, JJ ARMESTO, E BERLOW, J BLOOMFIELD, R DIRZO, E HUBER-SANWALD,
LF HUENNEKE, RB JACKSON, A KINZIG, R LEEMANS, DM LODGE, HA MOONEY, M OESTERHELD, N LEROY POFF, MT SYKES, BH WALKER, M WALTER \& DH WALL (2000) Global biodiversity scenarios for the year 2100 . Science 287: 1770-1774.

SAN MARTÍN J \& C DONOSO (1997) Estructura florística e impacto antrópico en el bosque Maulino de Chile. In: Armesto JJ, C Villagrán, \& MTK Arroyo (eds) Ecología de los bosques nativos de Chile: 153-168. Editorial Universitaria, Santiago, Chile.

SCHEINER SM \& J GUREVITCH (1993) Design and analysis of ecological experiments. Chapman \& Hall, New Cork, New York, USA. xv+445 pp.

SIMONETTI JA, AA GREZ \& RO BUSTAMANTE (2003) El valor de la matriz en la conservación ambiental. Ambiente \& Desarrollo (Chile) 18: 116-118

SNEATH PHA \& RR SOKAL (1973) Numerical taxonomy. Freeman \& Co., San Francisco, California, USA. 573 pp.

STATSOFT, INC (2000) STATISTICA for Windows (Computer program manual). Tulsa, Oklahoma, USA. $2,435 \mathrm{pp}$

STRONG DR, LAWTON JH \& SOUTHWOOD TRE (1984) Insects on plants: community patterns and mechanisms. Harvard University Press, Cambridge, Massachusetts, USA. 313 pp.

VERGARA PM \& JA SIMONETTI (2003) forest fragmentation and rhinocriptid nest predation in central Chile. Acta Oecologica 24: 285-288.

VERGARA PM \& JA SIMONETTI (in press) Avian responses to fragmentation of the Maulino in central Chile. Oryx (International Journal of Conservation). 